\title{
Simulating and Optimizing Hydrogen Production by Low-pressure Autothermal Reforming of Natural Gas using Non-dominated Sorting Genetic Algorithm-II
}

\author{
M. J. Azarhoosh, ${ }^{*}$ H. Ale Ebrahim, and S. H. Pourtarah \\ Department of Chemical Engineering, Petrochemical Center of Excellence, \\ Amirkabir University of Technology (Tehran Polytechnic), \\ Tehran 15875-4413, Iran
}

doi: 10.15255/CABEQ.2014.2158

Original scientific paper Received: December 13, 2014 Accepted: December 1, 2015

Conventional hydrogen production plants consist of natural gas steam reforming to $\mathrm{CO}+3 \mathrm{H}_{2}$ on Ni catalysts in a furnace, water-gas shift reaction for converting $\mathrm{CO}$ into $\mathrm{CO}_{2}$ and $\mathrm{CO}_{2}$ absorption. A new alternative method for highly endothermic steam reforming is autothermal reforming (steam reforming with air input to the reactor) without the need for external heating. In this study, hydrogen production by autothermal reforming for fuel cells (base case) was simulated based on a heterogeneous and one-dimensional model. In addition, the effect of operating variables on the system behavior was studied. Finally, Pareto-optimal solutions for the maximum molar flow rate of the produced hydrogen and methane conversion were determined by NSGA-II. There was a huge increase in the produced hydrogen molar flow to the base case, which showed the importance of optimizing autothermal reformers for hydrogen production.

Key words:

simulation, multi-objective optimization, natural gas, hydrogen production, autothermal reforming, genetic algorithms

\section{Introduction}

Environmental considerations will probably change automobile fuels from gasoline and gas-oil to hydrogen (as fuel cell) in the future. Problems of fossil fuels include producing gaseous pollutants, such as $\mathrm{NOx}, \mathrm{CO}$, and even $\mathrm{SO}_{2}$ (from incomplete-hydrotreated fuels), which need catalytic converters and greenhouse gas emission (such as $\mathrm{CO}_{2}$, $\mathrm{CH}_{4}, \mathrm{~N}_{2} \mathrm{O}$ ) from the exhaust with a drastic effect on global warming ${ }^{1}$. Hydrogen usage in fuel cells generates only harmless water vapor ${ }^{2}$. Another future promising application of hydrogen fuel cells may be in small power plants without pollutants or greenhouse gas emission. Nowadays, power plants of industrial countries are coal-based with high $\mathrm{SO}_{2}$, $\mathrm{NOx}, \mathrm{CO}_{2}$, mercury, and fly-ash emissions. Flue gas desulfurization of such power plants with $\mathrm{CaO}$ (dry method) or $\mathrm{Ca}(\mathrm{OH})$, (wet method) is a costly process $^{3}$. In addition, $\mathrm{SO}_{2}$ reaction with lime shows pore mouth closure and incomplete conversion problems due to high molar volume ratio of $\mathrm{CaSO}_{4}$ to $\mathrm{CaO}^{4}$.

The environmental preference of natural gas in terms of producing hydrogen over coal is a very interesting issue. Natural gas sweetening is very simple, whereas coal desulfurization is almost impossi-

"Corresponding author: e-mail: m.j.azarhoosh@aut.ac.ir ble. Moreover, the amount of greenhouse gas $\left(\mathrm{CO}_{2}\right)$ emissions from natural gas-based combustion is about $45 \%$ of coal-based power plants ${ }^{5,6}$.

Industrial hydrogen production plants are usually based on catalytic steam reforming (SR) of natural gas to synthesis gas $\left(\mathrm{CO}+3 \mathrm{H}_{2}\right)$, water-gas shift reaction for converting $\mathrm{CO}$ into $\mathrm{CO}_{2}, \mathrm{CO}_{2}$ absorption, and methanation of trace-remaining carbon oxides $^{7}$. Conventional steam reforming is a highly endothermic reaction and needs a big top-fired or side-fired furnace for external heating of Ni-packed tubes ${ }^{8}$. Steam reforming by methane as the feed stock has been extensively studied in the literature $^{9-12}$.

Another method for producing hydrogen or synthesizing gas from natural gas is partial oxidation method. This method includes a highly exothermic reaction with hot spot, sintering of active catalyst sites, and even run-away problems ${ }^{13-15}$.

An interesting alternative for steam reforming is the autothermal reforming method with internal heat generation by oxygen or air injection to the steam reforming system and elimination of its costly furnace ${ }^{16,17}$. ATR (autothermal reforming) combines thermal effects of partial oxidation and steam reforming reactions by feeding natural gas, water vapor, and air (or oxygen) into the reactor. Steam reforming and oxidation of methane occur simulta- 
neously in the presence of nickel catalyst. The heat generated from partial oxidation is absorbed by steam reforming; hence, the overall temperature which is decreased with respect to partial oxidation is acceptable. In recent years, considerable attention has been paid to autothermal reforming which has an interesting potential in industrial applications ${ }^{18-22}$; but, there have been only few works on reactor simulation and optimization. Behroozsarand et al. ${ }^{23}$ performed multi-objective optimization of an industrial autothermal reformer, which consisted of a noncatalytic partial oxidation chamber and a two-section catalytic steam reformer in order to produce syngas with $\mathrm{H}_{2} / \mathrm{CO}$ molar ratio of close to 1 for application in oxo-processes. Akbari et al. ${ }^{24}$ presented a numerical investigation of catalytic autothermal reforming of methane in a surface microreactor for mobile applications of hydrogen fuel cells. In Mohanty's ${ }^{25}$ study, real parameter non-dominated sorting genetic algorithm was used to obtain a Pareto optimal set of process parameters for producing synthesis gas from combined carbon dioxide reforming and partial oxidation of natural gas over a $\mathrm{Pt} / \mathrm{Al}_{2} \mathrm{O}_{3}$ catalyst.

In this work, low-pressure autothermal fixed bed reactor was simulated for producing hydrogen for fuel cells based on a heterogeneous and one-dimensional mathematical model. In most previous studies, the $\mathrm{Xu}$ and Froment (XF) kinetic model for steam reforming reaction was used but the Numaguchi and kikuchi (NK) kinetic model was used in this study. In addition, the effects of operating parameters on reactor behavior and outlet hydrogen mole fraction were studied. The non-dominated sorting genetic algorithm-II (NSGA-II) was then used for optimizing this system. Finally, the best conditions were determined for obtaining the maximum molar flow rate of hydrogen with reasonable unreacted methane. The hydrogen molar flow rate was calculated from the outlet gaseous mole fractions from simulation program by the equation below. Multiplication of mass flow rate of feed and outlet hydrogen weight fraction was used in this equation.

$$
\begin{gathered}
\dot{n}_{\mathrm{H}_{2}}\left(\mathrm{~mol} \mathrm{~s}^{-1}\right)= \\
=\frac{(\pi / 4) d_{r}^{2}(G)\left(2 y_{\mathrm{H}_{2}}\right)\left(1000 / M_{\mathrm{H}_{2}}\right)}{2 y_{\mathrm{H}_{2}}+18 y_{\mathrm{H}_{2} \mathrm{O}}+28 y_{\mathrm{CO}}+44 y_{\mathrm{CO}_{2}}+16 y_{\mathrm{CH}_{4}}+32 y_{\mathrm{O}_{2}}+28 y_{\mathrm{N}_{2}}}
\end{gathered}
$$

The optimization parameters were $\mathrm{H}_{2} \mathrm{O} / \mathrm{CH}_{4}$ and $\mathrm{O}_{2} / \mathrm{CH}_{4}$ in the feed, as well as feed stream flux and temperature.

\section{Literature review}

There are very few references to the use of Evolutionary Algorithm (EA) techniques in chemis- try and catalysis, which includes Genetic Algorithm (GA), Evolutionary Strategy (ES), Genetic Programming (GP), etc. The Evolutionary Strategy (ES) has been used for the selection and optimization of heterogeneous catalytic materials ${ }^{26-28}$. Genetic Programming has been employed very rarely. Baumes et al. ${ }^{29,30}$ showed two examples of this very powerful technique. Genetic Algorithms (GA) have been done by various groups, such as Pereira et al. ${ }^{31}$ They reported a study of the effect of Genetic Algorithm (GA) configurations on the performance of heterogeneous catalyst optimization. Also, Gobin et $a l .^{32,33}$ used multi-objective experimental design of experiments based on a genetic algorithm to optimize the combinations and concentrations of solid catalyst systems. Moreover, the genetic algorithm has been merged with a knowledge-based system ${ }^{34}$, and boosted on a GPU hardware to solve a zeolite structure $^{35,36}$. In addition, GA has been used for crystallography and XRD measurements ${ }^{37,38}$, and as an Active Learning method for effective sampling ${ }^{39}$.

Although a number of papers on the simulation of autothermal reforming are available, very few have tried to optimize the process conditions in order to obtain maximum benefit. Behroozsarand et al. performed the multi-objective optimization of an industrial autothermal reformer consisting of a non-catalytic partial oxidation (POX) chamber and a two-section catalytic steam reformer in order to produce syngas with $\mathrm{H}_{2} / \mathrm{CO}$ ratio of near 1 for application in Oxo-processes ${ }^{23}$. The autothermal reformer that was appropriate for methanol production and Fischer-Tropsch reactions was optimized using NSGA-II method in Azarhoosh et al. study ${ }^{40}$. The optimization parameters were determined for the hydrogen production of 2 and maximum methane conversion.

\section{Problem statement and objectives of the present study}

In this study, the fixed-bed autothermal reactor was simulated. It only had a catalyst bed, in which combustion and steam reforming reactions occurred simultaneously. First, the appropriate steady-state one-dimensional model was selected and presented for the autothermal reforming. Then, the differential equations of the related model were solved by suitable numerical methods for the simulation of the fixed-bed reactor and low-pressure autothermal reformer was simulated. The simulation framework was then used for predicting the effects of major operating variables, such as feed temperature, $\mathrm{O}_{2} / \mathrm{CH}_{4}$ molar ratio, and steam-to-methane $\left(\mathrm{H}_{2} \mathrm{O} / \mathrm{CH}_{4}\right)$ molar ratio on the behavior of the autothermal reactor. Finally, optimization of the autothermal reforming reactor was considered using non-dominated sorting genetic algorithm II (NSGA-II). The main objec- 
tives of autothermal reforming were maximum methane conversion and hydrogen production in the exit synthesis gas.

Specific objectives of this study were:

- Simulating a low-pressure auto-thermal reformer

- Predicting effects of main operating variables such as temperature, etc.

- Optimizing the ATR reformer to produce maximum hydrogen.

\section{Model description and solution procedure}

In this study, the fixed bed autothermal reactor, illustrated in Fig. 1, was simulated. It only had a catalyst bed on which combustion and steam reforming reactions occurred simultaneously.

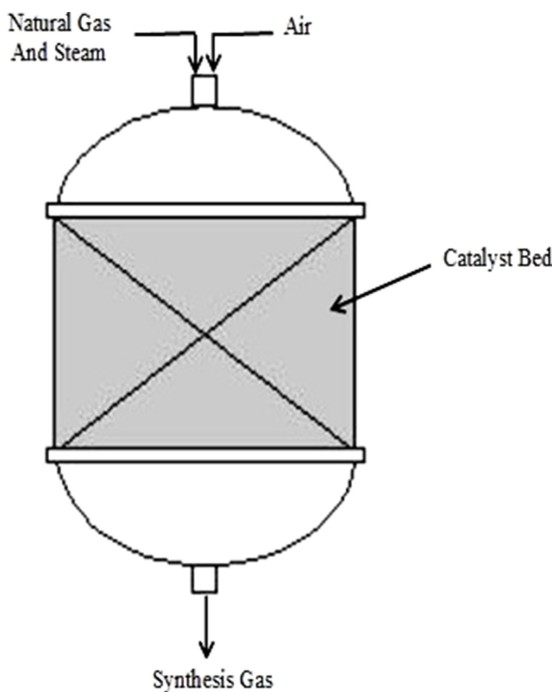

Fig. 1 - Scheme of a typical autothermal reformer

The mathematical modeling for autothermal reforming with internal heating by oxidation reaction was done by a steady-state one-dimensional heterogeneous model ${ }^{2,41}$. The following assumptions were made for modeling the autothermal reforming reactor:

- The feed gas has an ideal gas behavior.

- The catalyst pellets are isothermal: The main transport resistance inside the catalyst pellet is due to mass transfer, even in the case of highly exothermic reactions ${ }^{2,41}$.

- The reactor is at plug flow regime: Axial dispersion of heat and mass can be neglected.

- The packed bed reactor is assumed to be adiabatic.

- Effective binary diffusivities are used in the catalyst pellet.
- The catalyst pellet is semi-spherical and of uniform size.

- Total pressure of the reformer is constant: It is negligible in the investigated conditions ${ }^{41}$.

- The bed porosity is constant.

\section{Reaction kinetics model}

In a reforming process of natural gas, many reactions are likely to occur. If methane is considered to be the major dominating species in natural gas, the following set of reactions shown in Table 1 will be involved ${ }^{2}$.

Table 1 -Autothermal reactions ${ }^{2}$

\begin{tabular}{llc}
\hline \multicolumn{2}{c}{ Reaction } & $\begin{array}{c}\Delta H_{j}^{0} \\
\left(\mathrm{~kJ} \mathrm{~mol}^{-1}\right)\end{array}$ \\
\hline $\mathrm{R}_{1}$ : Steam reforming & $\mathrm{CH}_{4}+\mathrm{H}_{2} \mathrm{O} \rightleftharpoons \mathrm{CO}+3 \mathrm{H}_{2}$ & 206.2 \\
$\mathrm{R}_{2}$ : Water gas shift & $\mathrm{CO}+\mathrm{H}_{2} \mathrm{O} \rightleftharpoons \mathrm{CO}_{2}+\mathrm{H}_{2}$ & -41.1 \\
$\mathrm{R}_{3}$ : Total combustion & $\mathrm{CH}_{4}+2 \mathrm{O}_{2} \rightleftharpoons \mathrm{CO}_{2}+2 \mathrm{H}_{2}$ & -802.7 \\
$\mathrm{R}_{4}$ : Steam reforming & $\mathrm{CH}_{4}+2 \mathrm{H}_{2} \mathrm{O} \rightleftharpoons \mathrm{CO}_{2}+4 \mathrm{H}_{2}$ & 164.9 \\
$\mathrm{R}_{5}$ : Partial oxidation & $\mathrm{CH}_{4}+\frac{1}{2} \mathrm{O}_{2} \rightleftharpoons \mathrm{CO}+2 \mathrm{H}_{2}$ & -36 \\
$\mathrm{R}_{6}$ : Partial combustion & $\mathrm{CH}_{4}+\mathrm{O}_{2} \rightleftharpoons \mathrm{CO}_{2}+2 \mathrm{H}_{2}$ & -71 \\
$\mathrm{R}_{7}$ : Dry reforming & $\mathrm{CH}_{4}+\mathrm{CO}_{2} \rightleftharpoons 2 \mathrm{CO}+2 \mathrm{H}_{2}$ & 247 \\
$\mathrm{R}_{8}$ : Boudouard reaction & $2 \mathrm{CO}^{2} \rightleftharpoons \mathrm{C}_{2} \mathrm{CO}_{2}$ & -172 \\
$\mathrm{R}_{9}$ : Decomposition & $\mathrm{CH}_{4} \rightleftharpoons \mathrm{C}+2 \mathrm{H}_{2}$ & 75 \\
\hline
\end{tabular}

To reduce the complexity in the development and solution of the mathematical model, only the reactions with significant rates will be considered. The first three reactions prove to have significant rates $^{41,42}$. Therefore, other reactions were ignored in this modeling study.

As the reactor simulations concern the autothermal reforming of methane to synthesis gas on supported Ni catalysts, the rate equations for total combustion, steam reforming, and water-gas shift reactions have to be combined in the calculations. Kinetics of methane combustion (reaction 3 in Table 1) was taken from Trimm and $\mathrm{Lam}^{43}$. Since this kinetic model was derived for supported Pt catalysts, the corresponding adsorption parameters were adjusted for Ni (see Equation 4 in Table 2). For reactions 1 and 2 in Table 1, two of the most important models were the reforming model proposed by $\mathrm{Xu}$ and Froment, and the kinetic model taken from Numaguchi and Kikuchi ${ }^{9,42}$. These models will be referred to hereinafter as XF and NK models, respectively. The XF reforming model was obtained using relatively low temperatures $\left(773<T_{s}<848 \mathrm{~K}\right)$. During the indirect partial oxidation of methane to synthesis gas, however, high catalyst temperatures 
Table 2 - Reaction kinetic equations for nickel catalyst

$\frac{k_{1}\left(P_{\mathrm{CH}_{4}}-\frac{P_{\mathrm{H}_{2}}^{3} P_{\mathrm{CO}}}{K_{1} P_{\mathrm{H}_{2} \mathrm{O}}}\right)}{P_{\mathrm{CH}_{4}}^{\alpha_{1}} P_{\mathrm{H}_{2} \mathrm{O}}^{\beta_{1}}}, \alpha_{1}=0, \beta_{1}=0.596$
$R_{2}=\frac{k_{2}\left(P_{\mathrm{CO}}-\frac{P_{\mathrm{H}_{2}} P_{\mathrm{CO}_{2}}}{K_{2} P_{\mathrm{H}_{2} \mathrm{O}}}\right)}{P_{\mathrm{CH}_{4}}^{\alpha_{2}} P_{\mathrm{H}_{2} \mathrm{O}}^{\beta_{2}}}, \alpha_{2}=0, \beta_{2}=0$
$R_{3}=\frac{k_{3 \mathrm{a}} P_{\mathrm{CH}_{4}} P_{\mathrm{O}_{2}}}{\left(1+K_{\mathrm{CH}_{4}}^{\mathrm{ox}} P_{\mathrm{CH}_{4}}+K_{\mathrm{O}_{2}}^{\mathrm{ox}} P_{\mathrm{O}_{2}}\right)^{2}}+\frac{k_{3 \mathrm{~b}} P_{\mathrm{CH}_{4}} P_{\mathrm{O}_{2}}}{1+K_{\mathrm{CH}_{4}}^{\mathrm{ox}} P_{\mathrm{CH}_{4}}+K_{\mathrm{O}_{2}}^{\mathrm{ox}} P_{\mathrm{O}_{2}}}$

could occur due to the exothermal total combustion reaction $^{9,41}$. Hence, in this study, the kinetic model proposed by Numaguchi and Kikuchi, derived at higher catalyst temperatures (up to $1000 \mathrm{~K}$ ), was used to simulate adiabatic fixed- bed autothermal reactors $^{41,42}$. Langmuir-Hinshelwood rate equations for steam reforming towards $\mathrm{CO}$ and for the watergas shift reaction were proposed by the authors based on a rate-determining surface reaction step (see Equations 2 and 3 in Table 2) ${ }^{42}$. Table 2 shows the reaction kinetic equations for nickel catalyst.

Rate coefficients $k_{1}, k_{2}, k_{3 \mathrm{a}}$, and $k_{3 \mathrm{~b}}$ depended on temperature according to an Arrhenius type equation:

$$
k_{i}=A_{i}^{\prime} \exp \left(\frac{-E_{a c t}}{R T_{s}}\right)
$$

Values of pre-exponential factors and activation energies are presented in Table 3.

Table 3 -Arrhenius parameters for combustion, reforming, and water gas shift reactions

\begin{tabular}{c|c|c}
\hline Rate coefficient & \multicolumn{1}{c|}{$A_{i}{ }^{\prime}$} & $E_{a c t}\left(\mathrm{~kJ} \mathrm{~mol}^{-1}\right)$ \\
\hline$k_{1}$ & $2.62 \cdot 10^{5}$ & 86 \\
$k_{2}$ & $2.45 \cdot 10^{2}$ & 86 \\
$k_{3 a}$ & $4.5416 \cdot 10^{5}$ & 106.9 \\
$k_{3 b}$ & $3.8192 \cdot 10^{5}$ & 54.5 \\
\hline
\end{tabular}

*Units: $\left(k_{1}\right):$ mol atm ${ }^{-0.404} \mathrm{~kg}^{-1} \mathrm{~s}^{-1},\left(k_{2}\right): \mathrm{mol} \mathrm{atm}^{-1} \mathrm{~kg}^{-1} \mathrm{~s}^{-1}$, $\left(k_{3 a}, k_{3 b}\right): \mathrm{mol} \mathrm{atm}^{-2} \mathrm{~kg}^{-1} \mathrm{~s}^{-1}$

The first term of the oxidation rate equation (see Equation 4 in Table 2) accounts for the reaction between molecularly adsorbed methane and oxygen. The second term describes Eley-Rideal reaction between molecularly adsorbed methane and gaseous oxygen. The adsorption constant is written as:

$$
K_{i}^{o x}=A_{i} \exp \left(\frac{-\Delta H_{i}}{R T_{s}}\right)
$$

Standard $\mathrm{CH}_{4}$ and $\mathrm{O}_{2}$ adsorption enthalpies in the case of $\mathrm{Pt}$ and $\mathrm{Ni}$ were taken from Shustorovich (see Table 4$)^{44}$

Table 4 -Von't Hoff parameters for species adsorption

\begin{tabular}{ccc}
\hline Adsorption coefficient & $A_{i}\left(\mathrm{~atm}^{-1}\right)$ & $\Delta H_{i}\left(\mathrm{~kJ} \mathrm{~mol}^{-1}\right)$ \\
\hline$K_{\mathrm{CH}_{4}}^{\mathrm{ox}}$ & $1.26 \cdot 10^{-1}$ & -27.3 \\
$K_{\mathrm{O}_{2}}^{\mathrm{ox}}$ & $7.78 \cdot 10^{-7}$ & -92.8 \\
\hline
\end{tabular}

In Equations 2 and 3 (in Table 2), $K_{1}$ and $K_{2}$ are equilibrium constants of reactions 1 and 2. The equilibrium constants calculated at each temperature by Von't Hoff method and their parameters are presented in Table $5^{45}$ :

$$
\begin{gathered}
K_{j}^{\circ}=\exp \left(\frac{-\Delta G_{j}^{\circ}}{R T_{s}}\right) \\
\ln \frac{K_{j}}{K_{j}^{\circ}}=-\frac{\Delta H_{j}^{\circ}}{R}\left(\frac{1}{T_{s}}-\frac{1}{298}\right)
\end{gathered}
$$

Table 5-Standard enthalpies and Gibbs free energies of components

\begin{tabular}{cccc}
\hline Component & $\Delta H_{i}^{0}\left(\mathrm{~kJ} \mathrm{~mol}^{-1}\right)$ & $\Delta G_{i}^{0}\left(\mathrm{~kJ} \mathrm{~mol}^{-1}\right)$ \\
\hline $\mathrm{CH}_{4}$ & -74.5 & -50.5 \\
$\mathrm{CO}$ & -110.5 & -137.2 \\
$\mathrm{CO}_{2}$ & -393.5 & -394.4 \\
$\mathrm{H}_{2} \mathrm{O}$ & -241.8 & -228.6 \\
$\mathrm{H}_{2}$ & 0 & 0 \\
$\mathrm{O}_{2}$ & 0 & 0 \\
\hline
\end{tabular}

Rates of consumption or formation of species $i$ $(r)$ is determined by summing up the reaction rates of that species in all the reactions $(r)$. Effectiveness factors $\eta_{j}$ are used to account for the intra-particle transport limitation ${ }^{2,13,46}$. Therefore, the reaction rate of each species becomes:

$$
\begin{gathered}
r_{\mathrm{CH}_{4}}=-\eta_{1} r_{1}-\eta_{3} r_{3} \\
r_{\mathrm{CO}}=\eta_{1} r_{1}-\eta_{2} r_{2} \\
r_{\mathrm{CO}_{2}}=\eta_{2} r_{2}+\eta_{3} r_{3} \\
r_{\mathrm{O}_{2}}=-2 \eta_{3} r_{3} \\
r_{\mathrm{H}_{2}}=3 \eta_{1} r_{1}+\eta_{2} r_{2} \\
r_{\mathrm{H}_{2} \mathrm{O}}=-\eta_{1} r_{1}-\eta_{2} r_{2}+2 \eta_{3} r_{3}
\end{gathered}
$$


Effectiveness factors are computed along the reactor length using the following equation by integrating internal reaction rates ${ }^{47}$ :

$$
\eta_{j}=\frac{\int_{0}^{r_{p}} 4 \pi r^{2} r_{j} \mathrm{~d} r}{\frac{4}{3} \pi r_{p}{ }^{3} r_{j}^{s}}
$$

It is a measure of the relative importance of diffusion to reaction limitations and defined as the actual overall reaction rate to rate if the entire surface is exposed to $C_{i, s}^{s}$.

\section{Mass and energy balances}

The gas-phase and solid-phase mass and energy balance equations are presented in Table 6 along with the corresponding boundary conditions.

Table 6 - Mass and energy balance equations with boundary conditions

Gas phase

Mass balance: $G \frac{\mathrm{d}}{\mathrm{d} z}\left(\frac{C_{i}}{\rho_{f}}\right)+k_{g} a_{v}\left(C_{i}-C_{i, s}^{s}\right)=0$

Energy balance: $G C_{p} \frac{\mathrm{d} T}{\mathrm{~d} z}+h_{f} a_{v}\left(T-T_{s}\right)=0$

Solid phase

$$
\rho_{f} \frac{1}{r_{p}^{2}} \frac{D_{e, i}}{\xi^{2}} \frac{\mathrm{d}}{\mathrm{d} \xi}\left(\xi^{2} \frac{\mathrm{d}}{\mathrm{d} \xi}\left(\frac{C_{i, s}}{\rho_{f}}\right)+r_{i} \rho_{s}\right)=0
$$

$h_{f} a_{v}\left(T-T_{s}\right)+\left(1-\varepsilon_{B}\right) \sum_{i}\left(-\Delta_{f} H_{i}\right) \rho_{f} r_{i} \eta_{j}=0$

Gas phase boundary

condition

\begin{tabular}{lll}
\hline & $\xi=0$ & $\frac{\mathrm{d}}{\mathrm{d} \xi}\left(\frac{C_{i, s}}{\rho_{f}}\right)=0$ \\
$\begin{array}{l}\text { Solid phase boundary } \\
\text { conditions }\end{array}$ & $\rho_{f} \frac{D_{e, i}}{r_{p}} \frac{\mathrm{d}}{\mathrm{d} \xi}\left(\frac{C_{i, s}}{\rho_{f}}\right)=k_{g}\left(C_{i}-C_{i, s}\right)$
\end{tabular}

\section{Governing gas properties and transport coefficients}

\section{Mass transfer coefficient}

Mass transfer coefficient $\left(k_{\mathrm{g}}\right)$ is calculated using Chilton-Colburn j-factors $\left(J_{\mathrm{D}}^{\mathrm{g}}\right)^{48-50}$ :

$$
k_{g}=\frac{J_{D} G}{\rho_{f}}\left(\frac{\mu}{\rho_{f} D_{e, i}}\right)^{-\frac{2}{3}}
$$

where:

$$
\begin{gathered}
0.01<\operatorname{Re}<50 \Rightarrow J_{D}=0.84 \mathrm{Re}^{-0.51} \\
50<\operatorname{Re}<1000 \Rightarrow J_{D}=0.57 \mathrm{Re}^{-0.41} \\
\operatorname{Re}=\frac{d_{p} \rho_{f} G}{\mu} 2,50 \\
d_{p}=\frac{6(1-\varepsilon)}{a_{v}} 50
\end{gathered}
$$

Density of the gas mixtures is calculated by modifying the perfect gas law as follows ${ }^{49}$ :

$$
\rho_{f}=\frac{P_{t o t} M_{a v}}{R T}
$$

Viscosity of the components is accurately corrected as a function of temperature ${ }^{49}$ :

$$
\mu=\frac{A T^{B}}{1+\frac{C}{T}+\frac{D}{T^{2}}}
$$

in which A, B, C, and D constants are available $\mathrm{in}^{49,51}$. In order to predict the viscosity of gaseous mixtures, the Bromley and Wilke method was used $^{49}$.

\section{Heat transfer coefficient}

Heat transfer coefficient is calculated using Chilton-Colburn j-factors ${ }^{48-50}$ :

$$
h=J_{H} C_{P} G\left(\frac{C_{P} \mu}{K}\right)^{-\frac{2}{3}}
$$

where:

$$
\begin{aligned}
& 0.01<\operatorname{Re}<50 \Rightarrow J_{H}=0.84 \mathrm{Re}^{-0.51} \\
& 50<\operatorname{Re}<1000 \Rightarrow J_{H}=0.57 \mathrm{Re}^{-0.41}
\end{aligned}
$$

Heat capacity of the components is accurately corrected as a function of temperature ${ }^{45}$ :

$$
\begin{gathered}
\frac{C_{P, i}}{R}=A+B T+C T^{2}+D T^{-2} \\
C_{P}=\sum_{i} y_{i} C_{P, i}
\end{gathered}
$$

in which A, B, C, and D constants are available in reference ${ }^{45}$.

\section{Effective diffusion coefficients}

The corresponding effective diffusion coefficients were calculated from the molecular and Knudsen diffusion coefficients corrected for the pellet porosity and tortuosity $(0.53$ and 4.0 , respectively $)^{41}$ : 


$$
\frac{1}{D_{e, i}}=\frac{4}{0.53}\left(\frac{1}{D_{i, m}}+\frac{1}{D_{k, i}}\right)
$$

$D_{i, m}$ is molecular diffusion coefficient of species $i$ in multi-component mixtures. For calculating $D_{i, m}$, the molecular binary diffusion coefficients were calculated according to Wilke equation ${ }^{50,52}$.

From the kinetic theory of gases, the so-called Knudsen diffusivity can be formulated in Eq. $31^{50}$ :

$$
D_{k, i}=\frac{4}{3} \bar{r}\left(\frac{2}{\pi} \frac{R T}{M_{i}}\right)
$$

where $M_{i}$ is molecular weight of the diffusing species, and $\bar{r}$ is the average pore radius.

\section{Numerical solution procedure}

Step 1: Axial coordinate of reactor length is divided into the uniform grid with 1000 intervals.

Step 2: In each grid of the reactor length, the solid-phase (catalyst) is divided into the uniform grid with 40 intervals in radial coordinate. The solid-phase continuity equation (see Equation 18 in Table 6) is then solved in the first grid of the axial direction by means of the central finite deference method in MATLAB software. Thus, in first radial grid, concentration and partial pressure of each component in all the grids of the catalyst pellet are calculated by solving Equation 18.

Step 3: Using the calculated partial pressures, the effectiveness factor of each reaction is specified by numerical integration (see Equation 15).

Step 4: Ordinary equations for gas phase (Equations 16 and 17 in Table 6) are solved using Runge-Kutta method. Also, mole fraction and temperature of components are specified in the bulk gas for the second grid of the axial direction.

Step 5: The catalyst temperature for the second grid of the axial direction is calculated using Equation 19 (in Table 6).

This cycle is performed until the end of the reactor length. Therefore, using this method in all grids of the reactor, the dependent variables are calculated at all nodal points. The concentration profiles versus reactor length as well as pellet radius coordinates can be determined by this procedure.

\section{Non-dominated Sorting Genetic Algorithm-II (NSGA-II)}

The principles, on which the NSGA-II relies, are the same as those of the single-objective optimization. The strongest individuals (or chromosomes) are combined to create the offspring by crossover and mutation, and this scheme is repeated over many generations. However, the multi-objective optimization algorithm must consider the fact that there are many "best solutions", which modify the selection process. NSGA-II sorts individuals based on the non-domination rank and the crowding distance to ensure a high level of performance as well as good dispersion of results ${ }^{41,56-59}$. Fig. 2 shows the flowchart of non-dominated sorting genetic algorithm-II ${ }^{41,53,56,60}$.

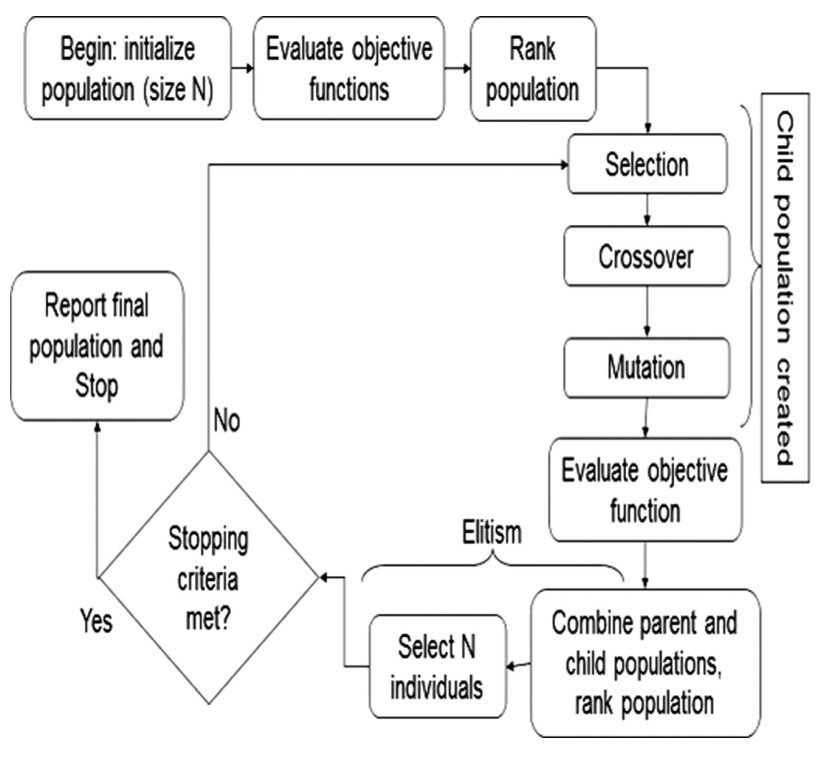

Fig. 2 - Flowchart of non-dominated sorting genetic algorithm-II program

\section{Results and discussion}

\section{Reactor dimensions and operating conditions}

The autothermal reactor and catalyst specifications were the same as reported by de Smet et al. ${ }^{41}$. The catalyst specifications are presented in Table 7 . The reactor dimensions as well as operating conditions for hydrogen-for-fuel-cell production are demonstrated in Table $8^{41}$. In the case of fuel-cell application, the fixed-bed catalytic autothermal reactor operated at atmospheric pressure. Beside methane and air, water vapor was added as a reactant in the reactor inlet to increase hydrogen formation and suppress coke deposition. In the applied mass-flux and catalyst pellet diameter, the pressure drop was assumed negligible.

Table 7 -Catalyst specifications

\begin{tabular}{lc}
\hline & Numaguchi and Kikuchi \\
\hline Catalyst & $\mathrm{Ni} / \mathrm{Al}_{2} \mathrm{O}_{3}$ \\
Density $\left(\mathrm{kg} \mathrm{m}^{-3}\right)$ & 1970 \\
Metal surface area $\left(\mathrm{m}^{2} \mathrm{~g}^{-1}\right)$ & 3.6 \\
\hline
\end{tabular}


Table 8 -Reactor and catalyst dimensions, operating conditions, and feed composition ${ }^{4 l}$

\begin{tabular}{lc}
\hline \multicolumn{1}{c}{ Reactor and catalyst } \\
\hline$d_{r}\left(\mathrm{~m}_{\mathrm{r}}\right)$ & 0.1 \\
$l_{r}\left(\mathrm{~m}_{\mathrm{r}}\right)$ & 0.5 \\
$\varepsilon_{b}\left(\mathrm{~m}_{\mathrm{g}}^{3} \mathrm{~m}_{\mathrm{r}}^{-3}\right)$ & 0.43 \\
$r_{p}\left(\mathrm{~m}_{\mathrm{p}}\right)$ & $2.5 \cdot 10^{-3}$ \\
\hline Operating conditions & 1 \\
$P_{\text {tot }}($ atm $)$ & 773 \\
$T(\mathrm{~K})$ & 0.15 \\
$G\left(\mathrm{~kg} \mathrm{~m}^{-2} \mathrm{~s}^{-1}\right)$ & \\
\hline Feed composition & 0.5 \\
$\mathrm{O}_{2} / \mathrm{CH}_{4}$ & 1.5 \\
$\mathrm{H}_{2} \mathrm{O} / \mathrm{CH}_{4}$ & Air \\
Oxygen source & \\
\hline
\end{tabular}

\section{Simulation results}

A fixed-bed reactor suitable for the operation of a fuel-cell was investigated. The calculated catalyst and bulk gas temperature profiles along the reactor co-ordinate are shown in Fig. 3 for NK reforming kinetics. In this figure, catalyst temperature increased first due to the large amount of heat produced in the methane oxidation reaction. Then, the catalyst temperature reached $1001 \mathrm{~K}$ and decreased consecutively as a result of the prevailing endothermic reforming reaction. The final temperature increase was due to the heat produced from the water-gas shift reaction. Relatively low value of the maximum catalyst temperature indicated that catalyst deactivation would not be very serious in this case. The catalyst temperature in the reactor inlet was approximately $40 \mathrm{~K}$ higher than the inlet gas phase temperature.

The calculated axial mole fraction profiles, obtained in case of the NK reforming kinetics, are

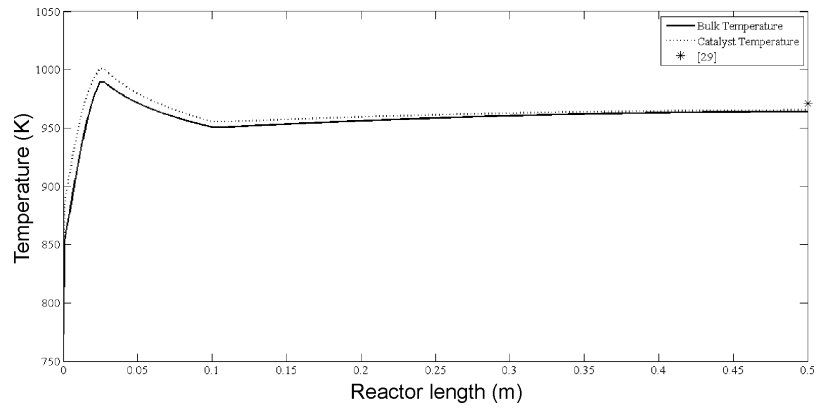

Fig. 3 - Bulk gas and catalyst temperatures versus length of the reactor

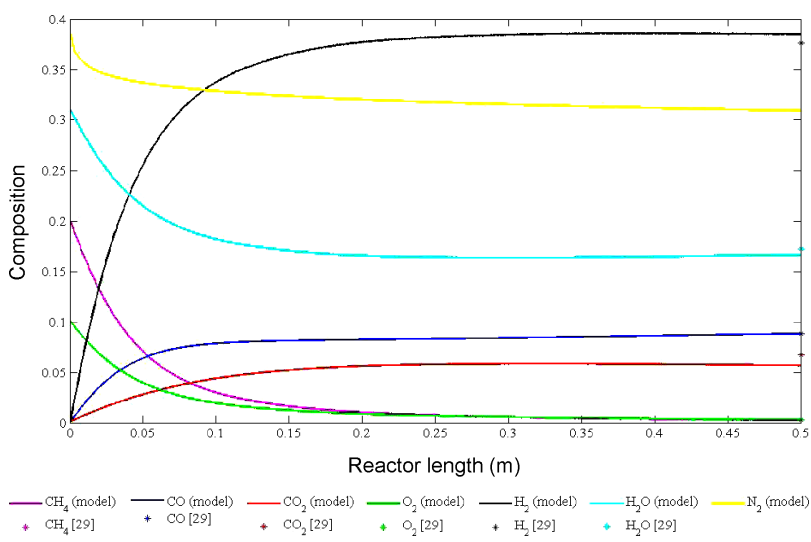

Fig. 4 - Components mole fraction profiles versus length of the reactor

shown in Fig. 4. This figure indicates that both methane and oxygen mole fractions decreased rapidly. As a result, significant amounts of $\mathrm{H}_{2}$ and $\mathrm{CO}$ were observed in the first part of the reactor. The simulated results of this work were in good agreement with those of De Smet et al. ${ }^{41}$ final temperature and mole fraction values, as demonstrated in Figs. 2 and 3.

Typical intra-particle mole-fraction profiles are shown in Fig. 5 in the case of simulations with NK reforming kinetics for $\mathrm{CH}_{4}$ and $\mathrm{H}_{2}$, respectively. The calculated mole fractions were plotted as a function of axial reactor coordinate as well as dimensionless pellet axis.

In these simulations, the calculated effectiveness factors varied considerably along the axial reactor coordinate, which indicated that it was necessary to consider intra-particle concentration
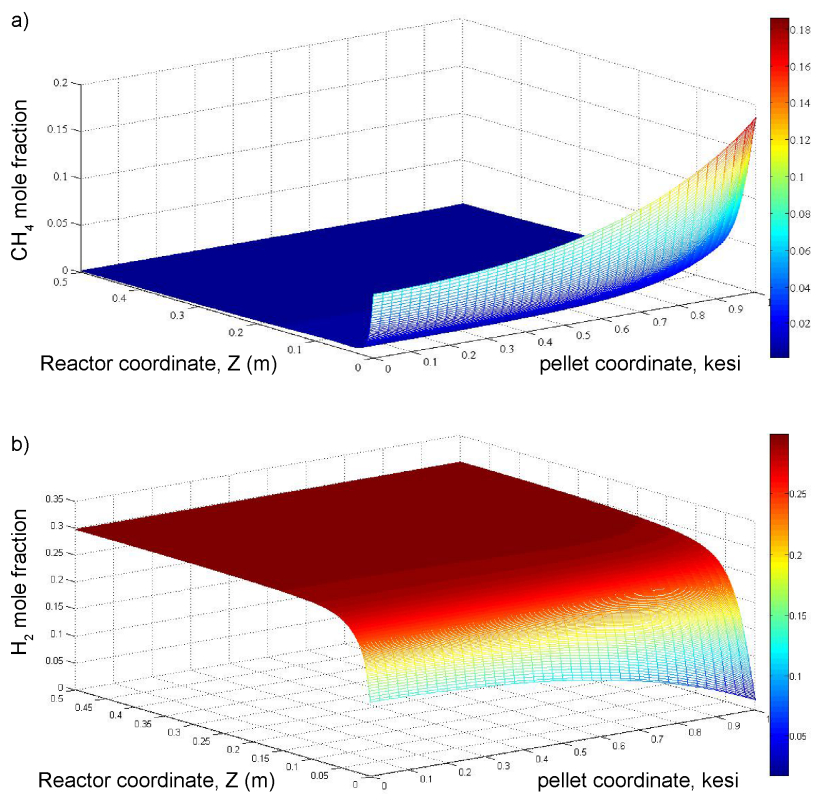

Fig. 5 - Intra-particle mole-fraction profiles of (a) methane and (b) hydrogen versus axial reactor coordinate and the dimensionless pellet coordinate 
gradients, and these gradients varied considerably along the reactor indeed. These effects were accounted for by solving the solid-phase continuity equations in each position in the fixed-bed reactor.

\section{Analysis of effective parameters}

The effects of variation on operating conditions versus base case on the system performance were studied. Performance of the reactor can be evaluated based on outlet hydrogen molar flow rate and final conversion of methane. Fig. 6 shows the effect of feed mass flux on final methane conversion $\left(X_{\mathrm{CH}_{4}}\right)$ and hydrogen molar flow. By increasing inlet gas mass flux with respect to the base case, final methane conversion was decreased due to less gas flow residence time and also reduced gas temperature along the reactor. In addition, as shown in this figure, from the base case $\left(0.15 \mathrm{~kg} \mathrm{~m}^{-2} \mathrm{~s}^{-1}\right.$ feed mass flux) to about $2.6 \mathrm{~kg} \mathrm{~m}^{-2} \mathrm{~s}^{-1}$, the outlet hydrogen production increased and then decreased by further increase in the feed mass flux.
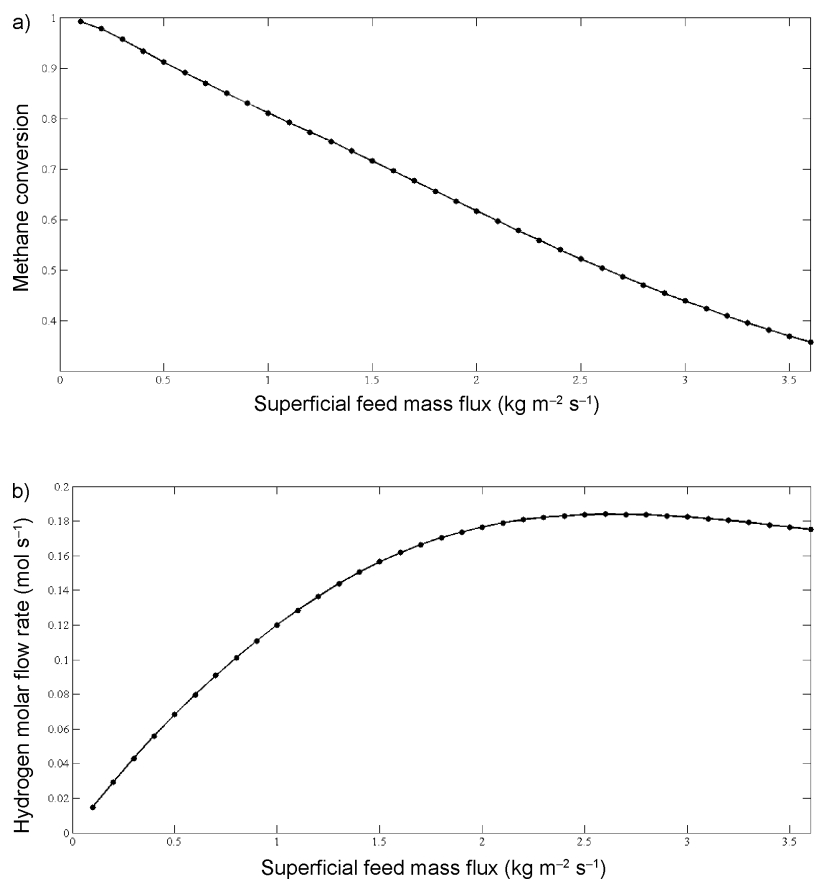

Fig. 6 - Effect of feed mass flux on (a) final methane conversion and (b) outlet hydrogen molar flow rate

Fig. 7 demonstrates the effect of inlet gas temperature on the final methane conversion and outlet hydrogen molar flow rate, respectively. Both of them were enhanced with increasing inlet gas temperature, and maximum conversion occurred in the maximum inlet operating gas temperature.

Variations of the outlet $\mathrm{H}_{2}$ molar flow and conversion of methane with the feed $\mathrm{H}_{2} \mathrm{O} / \mathrm{CH}_{4}$ ratio are presented in Fig. 8 along with other parameters at their baseline values (given in Table 8). At first,
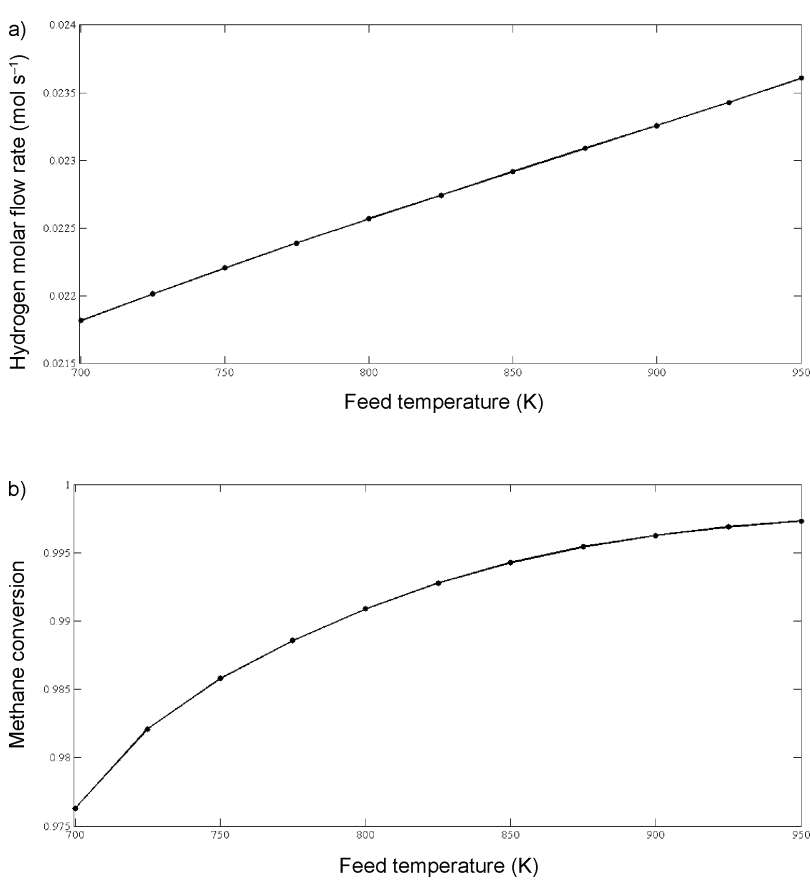

Fig. 7 - Effect of feed temperature on (a) hydrogen molar flow rate and (b) final methane conversion

increasing the inlet water content promoted the steam reforming reaction; thus, both methane conversion and hydrogen production increased by increasing water content of the feed mixture ${ }^{24}$. With the further increase in water content of the feed, methane conversion and produced hydrogen molar flow were decreased, which was due to decreasing air content of the feed, and exothermic oxidation rate.
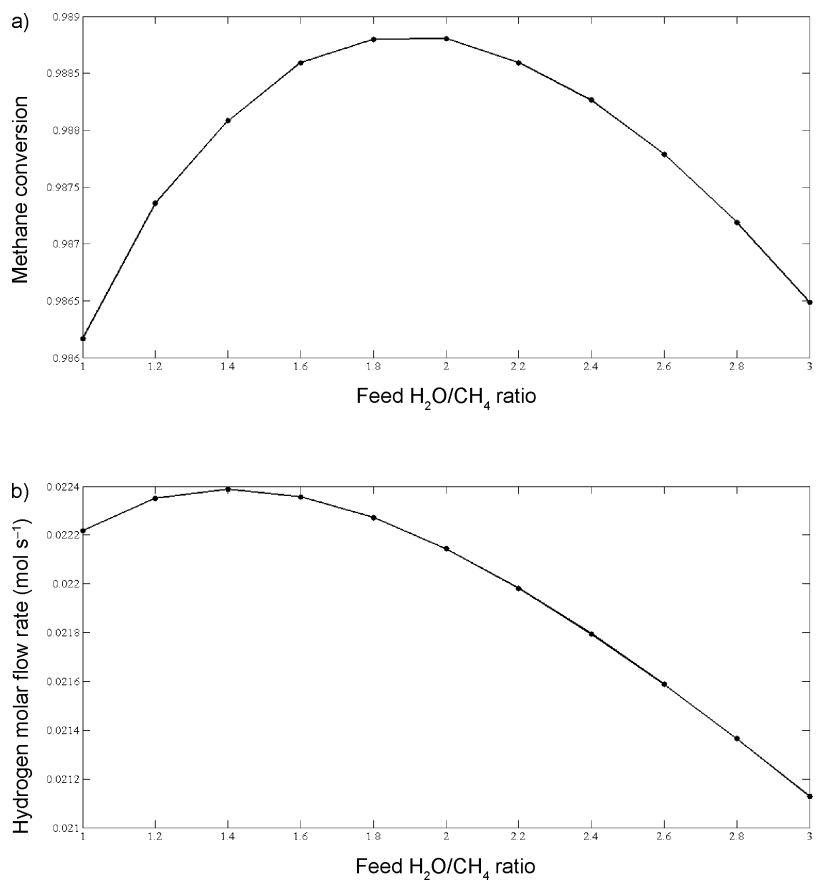

Fig. 8 - Effect of feed $\mathrm{H}_{2} \mathrm{O} / \mathrm{CH}_{4}$ on (a) final methane conversion and (b) hydrogen molar flow rate 
Fig. 9 shows the effect of $\mathrm{O}_{2} / \mathrm{CH}_{4}$ ratio on methane conversion and outlet hydrogen molar flow rate, respectively. By increasing oxygen in the feed, combustion of methane was increased. Therefore, methane conversion and hydrogen production would increase.
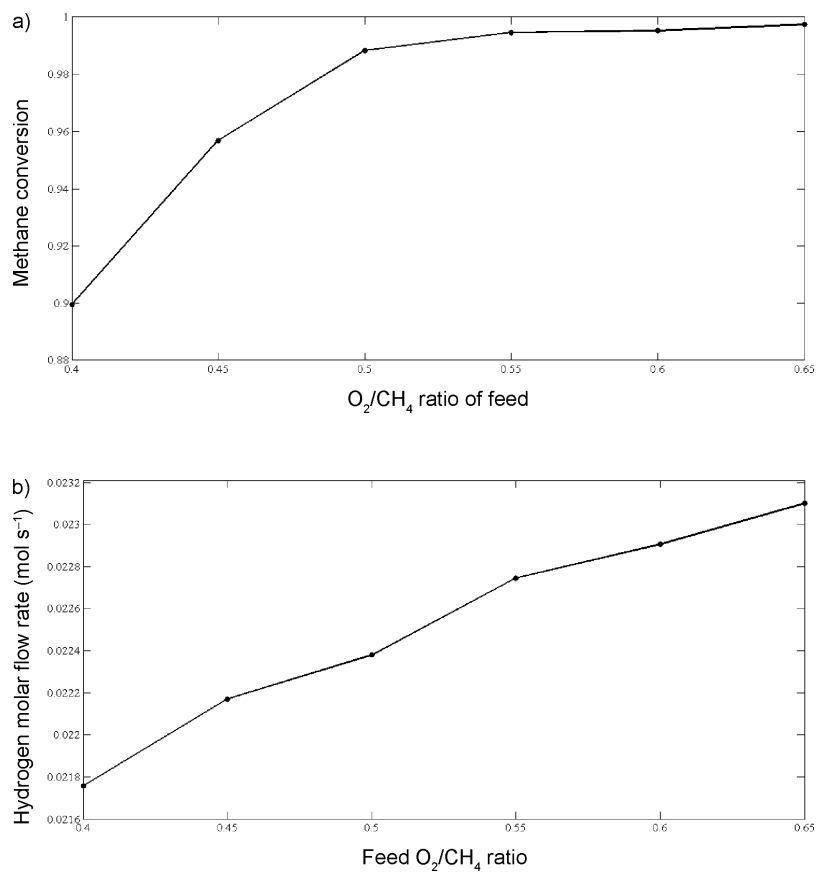

Fig. 9 - Effect of feed $\mathrm{O}_{2} / \mathrm{CH}_{4}$ on (a) final methane conversion and (b) hydrogen molar flow rate

\subsection{Optimization results using NSGA-II}

Non-dominated sorting genetic algorithm-II (NSGA-II) was used to optimize and obtain Pareto-optimal solutions. Population size of 100 was chosen with crossover of 0.7 and mutation probability of 0.05 . Input parameters of NSGA-II are given in Table 9.

Table 9 -Input parameters of NSGA-II

\begin{tabular}{lc}
\hline \multicolumn{1}{c|}{ Parameter name } & Method and value \\
\hline Number of decision variables & 4 \\
Number of objectives & 2 \\
Population size & 100 \\
Crossover method & Arithmetic crossover \\
Crossover probability & 0.7 \\
Mutation method & Gauss method \\
Mutation probability & 0.05 \\
\hline
\end{tabular}

The optimization problem was considered for a fuel-cell unit. It can logically search for operating scenarios that will maximize methane conversion and produced hydrogen molar flow simultaneously. Performing an NSGA-II optimization method with both of them as objectives can identify such scenarios. The optimization problem can be expressed mathematically as follows:

Objective 1:

Maximizing methane conversion $\left(X_{\mathrm{CH}_{4}}\right)$

Objective 2:

Maximizing produced hydrogen $\left(\dot{n}_{\mathrm{H}_{2}}\right)$

subject to:

$773 \mathrm{~K} \leq$ feed temperature $\leq 973 \mathrm{~K}$

$0.1 \mathrm{~kg} \mathrm{~m}^{-2} \mathrm{~s}^{-1} \leq$ superficial feed mass flux $\leq 1 \mathrm{~kg} \mathrm{~m}^{-2} \mathrm{~s}^{-1}$

$$
\begin{gathered}
0.4 \leq\left(\frac{\mathrm{O}_{2}}{\mathrm{CH}_{4}}\right)_{\text {inlet }} \leq 0.6 \\
1 \leq\left(\frac{\mathrm{H}_{2} \mathrm{O}}{\mathrm{CH}_{4}}\right)_{\text {inlet }} \leq 3
\end{gathered}
$$

Other parameters were the same as the base case. Higher limit of the feed temperature constraint of the autothermal reformer $(973 \mathrm{~K})$ was selected based on the lifetime of Ni catalyst in the fixed-bed reactor. Very high inlet gas temperatures were not recommended because of economic aspects, producing high catalyst temperature, and thus catalyst deactivation due to coke formation and even catalyst destruction by sintering ${ }^{23}$. Also, at low temperatures (below $773 \mathrm{~K}$ ), the first objective function $\left(\mathrm{CH}_{4}\right.$ conversion) was decreased; therefore, the lower limit $(773 \mathrm{~K})$ was appropriate.

At low $\mathrm{O}_{2} / \mathrm{CH}_{4}$ (below 0.4), methane conversion decreased and catalysts were prone to coking. Also, at high $\mathrm{O}_{2} / \mathrm{CH}_{4}$, hot spot formation in the catalyst increased due to the fast oxidation reaction; therefore, the higher limit (0.6) was appropriate. According to the literature and industrial autothermal reformer ${ }^{41}$, the lower limit of $\mathrm{H}_{2} \mathrm{O} / \mathrm{CH}_{4}$ was set at 1 to avoid carbon formation on the catalyst, which occurred at low value of $\mathrm{H}_{2} \mathrm{O} / \mathrm{CH}_{4}$. Also, very high $\mathrm{H}_{2} \mathrm{O} / \mathrm{CH}_{4}$ ratio adversely affected the process economics because of the energy requirement for heating up the feed.

Different operations were performed for 200 generations to obtain non-dominated Pareto-optimal solutions. A Pareto-optimal set is a series of solutions that are non-dominated with respect to each other. While moving from one Pareto solution to another, there is always a certain amount of sacri- 
Table 10 -Non-dominated Pareto-optimal solutions after 200 generations

\begin{tabular}{|c|c|c|c|c|c|c|}
\hline No. & $T_{\text {Feed }}\left({ }^{\circ} \mathrm{C}\right)$ & $G\left(\mathrm{~kg} \mathrm{~m}^{-2} \mathrm{~s}^{-1}\right)$ & $\left(\frac{\mathrm{O}_{2}}{\mathrm{CH}_{4}}\right)_{\text {inlet }}$ & $\left(\frac{\mathrm{H}_{2} \mathrm{O}}{\mathrm{CH}_{4}}\right)_{\text {inlet }}$ & $\dot{n}_{\mathrm{H}_{2}}\left(\mathrm{~mol} \mathrm{~s}^{-1}\right)$ & $X_{\mathrm{CH}_{4}}$ \\
\hline 1 & 933.7611 & 0.262525 & 0.541651 & 1.362340 & 0.039055 & 0.997087 \\
\hline 2 & 957.2295 & 0.959743 & 0.539643 & 1.410670 & 0.138199 & 0.961032 \\
\hline 3 & 962.8186 & 0.481647 & 0.539388 & 1.461741 & 0.072425 & 0.996458 \\
\hline 4 & 963.7707 & 0.785450 & 0.543921 & 1.460374 & 0.115266 & 0.977885 \\
\hline 5 & 963.6966 & 0.720830 & 0.542539 & 1.464961 & 0.106276 & 0.981430 \\
\hline 6 & 961.9038 & 0.948793 & 0.541008 & 1.454275 & 0.137244 & 0.965171 \\
\hline 7 & 963.1080 & 0.657087 & 0.544527 & 1.485736 & 0.097360 & 0.986971 \\
\hline 8 & 962.4242 & 0.604525 & 0.542668 & 1.468356 & 0.089914 & 0.989339 \\
\hline 9 & 963.0765 & 0.561418 & 0.541577 & 1.488307 & 0.083864 & 0.992868 \\
\hline 10 & 960.6819 & 0.892967 & 0.539940 & 1.420346 & 0.129559 & 0.966901 \\
\hline 11 & 963.8173 & 0.597917 & 0.544491 & 1.479203 & 0.089095 & 0.991465 \\
\hline 12 & 962.6552 & 0.888731 & 0.542163 & 1.446609 & 0.129246 & 0.969691 \\
\hline 13 & 961.9893 & 0.820658 & 0.543550 & 1.470219 & 0.119958 & 0.975125 \\
\hline 14 & 963.6072 & 0.684760 & 0.544456 & 1.483548 & 0.101257 & 0.985073 \\
\hline 15 & 963.0931 & 0.706699 & 0.544717 & 1.488730 & 0.104288 & 0.983708 \\
\hline 16 & 963.8856 & 0.548701 & 0.544011 & 1.481949 & 0.082164 & 0.995525 \\
\hline 17 & 964.0712 & 0.532209 & 0.543538 & 1.483448 & 0.079810 & 0.996157 \\
\hline 18 & 962.5524 & 0.875058 & 0.542785 & 1.476869 & 0.127398 & 0.971532 \\
\hline 19 & 962.8281 & 0.845776 & 0.542171 & 1.461865 & 0.123420 & 0.972825 \\
\hline 20 & 959.5964 & 0.826032 & 0.543833 & 1.452176 & 0.120518 & 0.973839 \\
\hline
\end{tabular}

fice in one objective(s) to achieve a certain amount of gain in other(s) ${ }^{23}$. The Pareto-optimal solution sets after 200 generations are shown in Table 10 and Fig. 10.

By comparing the solutions (chromosomes) in Table 10, it seems that chromosome 2 was the best solution, because it had the maximum molar rate and reasonable methane conversion. It is obvious that there was a huge increase in the produced hydrogen molar flow to the base case (from 0.0223 to $0.1382 \mathrm{~mol} \mathrm{~s}^{-1}$ ), which showed the importance of optimizing the autothermal reformers for hydrogen production.

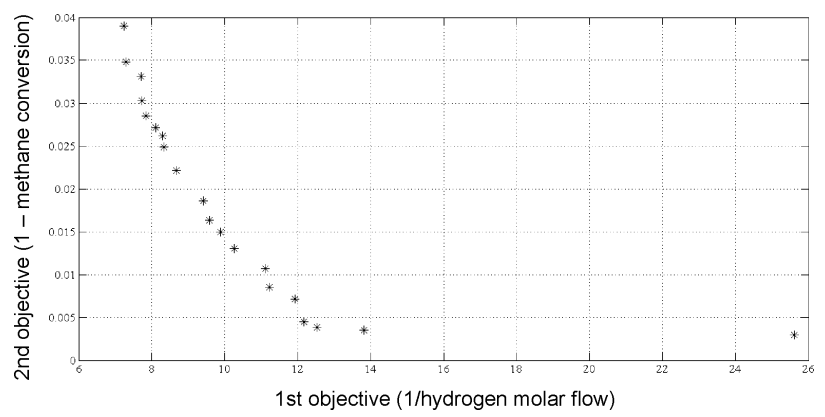

Fig. 10 - Non-dominated Pareto optimal solutions after 200 generations

\section{Conclusions}

A steady-state one-dimensional heterogeneous reactor model was used to simulate adiabatic fixed bed catalytic autothermal reactor for hydrogen production. Intra-particle concentration gradients were explicitly taken into account by solving the corresponding continuity equations in each position along the reactor coordinate. Effects of operating parameters such as inlet gas temperature, inlet gas mass flux, inlet $\mathrm{O}_{2} / \mathrm{CH}_{4}$, and $\mathrm{H}_{2} \mathrm{O} / \mathrm{CH}_{4}$ ratios on the system behavior were also studied. Finally, the autothermal reformer for hydrogen production was optimized using NSGA-II method. The optimization parameters were determined for the maximum hydrogen production rate and methane conversion. These parameters were determined for feed temperature, feed mass flux, inlet $\mathrm{O}_{2} / \mathrm{CH}_{4}$, and $\mathrm{H}_{2} \mathrm{O}$ / $\mathrm{CH}_{4}$ ratios as $957.2 \mathrm{~K}, 0.960 \mathrm{~kg} \mathrm{~m}^{-2} \mathrm{~s}^{-1}, 0.540$, and 1.410 , respectively. In this optimum condition, the produced outlet hydrogen molar flow and final methane conversion were $0.138 \mathrm{~mol} \mathrm{~s}^{-1}$ and 0.961 , respectively. It can be seen that there was a huge increase in the produced hydrogen molar flow to the base case and optimization was necessary for this system. 


\section{Nomenclature}

$A_{i} \quad$ - Pre-exponential factor of species $i$, atm

$A_{i}{ }^{\prime} \quad$ - Pre-exponential factor of reaction $i$, reaction dependent

$a_{v} \quad-$ External pellet surface area per unit reactor volume, $\mathrm{m}^{-1}$

$C_{i}-$ Molar concentration of species $i$ at bulk gas, $\mathrm{mol} \mathrm{m}^{-3}$

$C_{i}^{o} \quad-$ Inlet molar concentration of species $i$ at bulk gas, mol m${ }^{-3}$

$C_{i s}$ - Intra-particle molar concentration of species $i$, mol m${ }^{-3}$

$C_{i, s}{ }^{s}$ - Molar concentration of species $i$ at the external pellet surface, $\mathrm{mol} \mathrm{m}^{-3}$

$C_{p} \quad$ - Specific heat at constant pressure, $\mathrm{J} \mathrm{kg}^{-1} \mathrm{~K}^{-1}$

$C_{p, i}-$ Specific heat of component $i, \mathrm{~J} \mathrm{~kg}^{-1} \mathrm{~K}^{-1}$

$D_{e, i}$ - Effective diffusion coefficient of species $i$ in catalyst, $\mathrm{m}^{2} \mathrm{~s}^{-1}$

$D_{k, i} \quad-$ Knudsen diffusion coefficients, $\mathrm{m}^{2} \mathrm{~s}^{-1}$

$D_{i m}$ - Molecular diffusion coefficients, $\mathrm{m}^{2} \mathrm{~s}^{-1}$

$d_{r} \quad-$ Reactor diameter, $\mathrm{m}$

$E_{\text {act }}$ - Activation energy, $\mathrm{J} \mathrm{mol}^{-1}$

$G$ - Superficial feed mass flux, $\mathrm{kg} \mathrm{m}^{-2} \mathrm{~s}^{-1}$

$h_{f} \quad$ - Gas-to-solid heat transfer coefficient, $\mathrm{W} \mathrm{m} \mathrm{m}^{-2} \mathrm{~K}^{-1}$

$J_{D} \quad$ - Mass transfer Chilton-Colburn j-factor

$J_{H} \quad$ - Heat transfer Chilton-Colburn j-factor

$K$ - Conduction heat transfer coefficient, $\mathrm{W} \mathrm{m} \mathrm{s}{ }^{-1}$

$K_{i}^{o x}$ - Adsorption constant for component $i$ in combustion reaction, atm $^{-1}$

$K_{j} \quad$ - Equilibrium constant of reaction $j$, reaction dependent

$K_{j}^{o} \quad$ - Equilibrium constant of reaction $j$ at $25^{\circ} \mathrm{C}$, reaction dependent

$k_{i} \quad-$ Reaction rate constant of reaction $i$, reaction dependent

$K_{g} \quad$ - Gas-to-solid mass transfer coefficient, $\mathrm{m} \mathrm{s}^{-1}$

$l_{r}^{g} \quad-$ Reactor length, $\mathrm{m}$

$M_{\text {ave }}$ - Molecular weight of gaseous mixture, $\mathrm{g} \mathrm{mol}^{-1}$

$M_{i} \quad$ - Molecular weight of species $i, \mathrm{~g} \mathrm{~mol}^{-1}$

$\dot{n}_{\mathrm{H}_{2}} \quad$ - Outlet hydrogen molar flow

$P_{i} \quad$ - Partial pressure of component $i$, atm

$P_{\text {tot }} \quad-$ Total pressure, atm

$R \quad$ - Universal gas constant, atm $\mathrm{m}^{3} \mathrm{~mol}^{-1} \mathrm{~K}^{-1}$

$r \quad$ - Radius reactor co-ordinate, $\mathrm{m}$

$r_{i} \quad-$ Rate of component $i$ production, $\mathrm{mol} \mathrm{kg}^{-1} \mathrm{~s}^{-1}$

$r_{j} \quad-$ Rate of reaction $j(j=1,2,3), \mathrm{mol} \mathrm{kg}^{-1} \mathrm{~s}^{-1}$

$r_{i}^{s} \quad-$ Rate of reaction $j(j=1,2,3)$ at the external pellet surface, $\mathrm{mol} \mathrm{kg}^{-1} \mathrm{~s}^{-1}$

$r_{p} \quad-$ Pellet radius, $\mathrm{m}$

$\bar{r} \quad-$ Average pore radius

$T$ - Gas-phase temperature, $\mathrm{K}$

$T^{\circ} \quad$ - Inlet gas-phase temperature, $\mathrm{K}$

$T_{\text {s }} \quad-$ Solid temperature, $\mathrm{K}$

$X_{\mathrm{CH}_{4}}$ - Methane conversion

$y_{i} \quad$ - Mole fraction of species $i$ $z \quad-$ Axial reactor co-ordinate, $\mathrm{m}$

$\rho_{f} \quad-$ Fluid density

$\rho_{s} \quad-$ Catalyst density

$\eta_{i} \quad-$ Effectiveness factor of reaction $i$

$\xi-$ Dimensionless pellet co-ordinate

$\varepsilon \quad-$ Catalyst porosity

$\varepsilon_{B} \quad-$ Void fraction of packing

$\mu \quad-$ Viscosity of gaseous mixture, $\mathrm{kg} \mathrm{m}^{-2} \mathrm{~s}^{-1}$

$\Delta H_{i}$ - Standard adsorption enthalpy of component $i$, $\mathrm{J} \mathrm{mol}^{-1}$

$\Delta H_{i}^{o}$ - Standard adsorption enthalpy of component $i$ at $25{ }^{\circ} \mathrm{C}, \mathrm{J} \mathrm{mol}^{-1}$

$\Delta H_{j}^{o}$ - Standard adsorption enthalpy of reaction $j$ at $25{ }^{\circ} \mathrm{C}, \mathrm{J} \mathrm{mol}^{-1}$

$\Delta G_{i}^{o}-$ Gibbs free energy of component $i$ at $25^{\circ} \mathrm{C}$, $\mathrm{J} \mathrm{mol}^{-1}$

$\Delta G_{j}-$ Gibbs free energy of reaction $j, \mathrm{~J} \mathrm{~mol}^{-1}$

$\Delta G_{j}^{o}-$ Gibbs free energy of reaction $j$ at $25^{\circ} \mathrm{C}, \mathrm{J} \mathrm{mol}^{-1}$

$-\Delta_{f} H_{i}-$ Heat of formation of species $i, \mathrm{~J} \mathrm{~mol}^{-1}$

\section{References}

1. Gupta, H., Fan, L. S., Carbonation-Calcination Cycle Using High Reactivity Calcium Oxide for Carbon Dioxide Separation from Flue Gas, Ind. Eng. Chem. Res. 41 (2002) 4035. doi: http://dx.doi.org/10.1021/ie0108671

2. Halabi, M. H., de Croon, M. H. J. M., van der Schaaf, J., Cobden, P. D. Schouten, J. C., Modeling and analysis of autothermal reforming of methane to hydrogen in a fixed bed reformer, Chem. Eng. J. 137 (2008) 568. doi: http://dx.doi.org/10.1016/j.cej.2007.05.019

3. Kirk-Othmer, Encyclopedia of Chemical Technology. 5th ed. Vol. 12. John Wiley and Sons, New York, 2007.

4. Georgakis, C., Chang, C. W., Szekely, J., A changing grain size model for gas-solid reactions, Chem. Eng. Sci. 34 (1979) 1072.

doi: http://dx.doi.org/10.1016/0009-2509(79)80012-3

5. Dawe, R. A., Modern Petroluem Technology, 6th ed, Vol. 1, John Wiley and Sons, New York, 2000.

6. Adamson, K. A., Stationary Fuel Cells: An Overview, Elsevier, Amsterdam, 2007.

7. Gary, J. H., Handwerk G. E., Kaiser, M. J., Petroluem Refining: Technology and Economics, 5th ed, Marcel Dekker, Inc., New York, 2007.

8. Grevskott, S., Rusten, T., Hillestad, M., Edwin, E., Olsvik, $O$., Modelling and simulation of a steam reforming tube with furnace, Chem. Eng. Sci. 56 (2001) 597. doi: http://dx.doi.org/10.1016/S0009-2509(00)00265-7

9. Xu, J., Froment, G. F., Methane steam reforming, methanation and water-gas shift: I. Intrinsic kinetics. AICHE J. 35 (1989) 88. doi: http://dx.doi.org/10.1002/aic.690350109

10. Barbieri, G., Di Maio, F. P., Simulation of the Methane Steam Re-forming Process in a Catalytic Pd-Membrane Reactor, Ind. Eng. Chem. Res. 36 (1997) 2121. doi: http://dx.doi.org/10.1021/ie9601615

11. Zhu, T., van Grootel, P. W., Filot, I. A. W., Sun, S. G., van Santen, R. A., Hensen, E. J. M., Microkinetics of steam methane reforming on platinum and rhodium metal surfaces, J Catal. 297 (2013) 227. doi: http://dx.doi.org/10.1016/j.jcat.2012.10.010 
12. Ni, M., 2D heat and mass transfer modeling of methane steam reforming for hydrogen production in a compact reformer, Energ. Convers. Manage. 65 (2013) 155. doi: http://dx.doi.org/10.1016/j.enconman.2012.07.017

13. De Groote, A. M., Froment, G. F., Simulation of the catalytic partial oxidation of methane to synthesis gas, Appl. Catal. A-Gen. 138 (1996) 245.

doi: http://dx.doi.org/10.1016/0926-860X(95)00299-5

14. Basile, A., Paturzo, L., Laganà, F., The partial oxidation of methane to syngas in a palladium membrane reactor: simulation and experimental studies, Catal. Today 67 (2001) 65. doi: http://dx.doi.org/10.1016/S0920-5861(01)00266-8

15. Li, B., Li, H., Weng, W. Z., Zhang, Q., Huang, C. J., Wan, $H$. L., Synthesis gas production from partial oxidation of methane over highly dispersed $\mathrm{Pd} / \mathrm{SiO} 2$ catalyst, Fuel $\mathbf{1 0 3}$ (2013) 1032. doi: http://dx.doi.org/10.1016/j.fuel.2012.09.059

16. Dybkjaer, I., Tubular reforming and autothermal reforming of natural gas - an overview of available processes, Fuel Process Technol. 42 (1995) 85.

doi: http://dx.doi.org/10.1016/0378-3820(94)00099-F

17. Ahmed, S., Krumpelt, M., Hydrogen from hydrocarbon fuels for fuel cells, Int. J. Hydrogen Energ. 26 (2001) 291. doi: http://dx.doi.org/10.1016/S0360-3199(00)00097-5

18. de Souza, A. E. A. M., Maciel, L. J. L., de Lima Filho, N. M., de Abreu, C. A. M., Catalytic activity evaluation for hydrogen production via autothermal reforming of methane, Catal. Today 149 (2010) 413. doi: http://dx.doi.org/10.1016/j.cattod.2009.06.003

19. Chen, W. H., Lin, M. R., Lu, J. J., Chao, Y., Leo, T. S., Thermodynamic analysis of hydrogen production from methane via autothermal reforming and partial oxidation followed by water gas shift reaction, Int. J. Hydrogen Energ. 35 (2010) 11787.

doi: http://dx.doi.org/10.1016/j.ijhydene.2010.08.126

20. Simakov, D. S. A., Sheintuch, M., Model-based optimization of hydrogen generation by methane steam reforming in autothermal packed-bed membrane reformer, AICHE J. 57 (2011) 525 . doi: http://dx.doi.org/10.1002/aic.12265

21. Hoang, D. L., Chan, S. H., Ding O. L., Hydrogen production for fuel cells by autothermal reforming of methane over sulfide nickel catalyst on a gamma alumina support, J. Power Sources 159 (2006) 1248.

doi: http://dx.doi.org/10.1016/j.jpowsour.2005.11.094

22. Yan, Y., Zhang, J., Zhang, L., Properties of thermodynamic equilibrium-based methane autothermal reforming to generate hydrogen, Int. J. Hydrogen Energ. 38 (2013) 15744. doi: http://dx.doi.org/10.1016/j.ijhydene.2013.06.007

23. Behroozsarand, A., Ebrahimi, H., Zamaniyan, A., Multiobjective Optimization of Industrial Autothermal Reformer for Syngas Production Using Nonsorting Genetic Algorithm II, Ind. Eng. Chem. Res. 48 (2009) 7529. doi: http://dx.doi.org/10.1021/ie900259n

24. Akbari, M. H., Ardakani, A. H. S., Tadbir, M. A., A microreactor modeling, analysis and optimization for methane autothermal reforming in fuel cell applications. Chem. Eng J. 166 (2011) 1116. doi: http://dx.doi.org/10.1016/j.cej.2010.12.044

25. Mohanty, S., Multiobjective optimization of synthesis gas production using non-dominated sorting genetic algorithm, Comput. Chem. Eng. 30 (2006) 1019. doi: http://dx.doi.org/10.1016/j.compchemeng.2006.01.002

26. Clerc, F., Lengliz, M., Farrusseng, D., Mirodatos, C., Pereira, S. R. M., Rakotomalala, R., Library design using genetic algorithms for catalyst discovery and optimization, Review of Scientific Instruments 76 (2005) 062208. doi: http://dx.doi.org/10.1063/1.1906086

27. Askari, S., Halladj, R., Azarhoosh, M. J., Modeling and Optimization of Catalytic Performance of SAPO-34 Nanocatalysts Synthesized Sonochemically Using a new hybrid of Non-dominated Sorting Genetic Algorithm-II based Artificial Neural Networks (NSGA-II-ANN), RSC Advances 5 (2015) 52788 doi: http://dx.doi.org/10.1039/C5RA03764F

28. Bakhshi Ani, A., Ale Ebrahim, H., Azarhoosh, M. J., Simulation and Multi-Objective Optimization of a Trickle-Bed Reactor for Diesel Hydrotreating by a Heterogeneous Model using Non-Dominated Sorting Genetic Algorithm-II, Energy \& Fuels 29 (2015) 3041. doi: http://dx.doi.org/10.1021/acs.energyfuels.5b00467

29. Baumes, L. A., Blansché, A., Serna, P., Tchougang, A., Lachiche, N., Collet, P., Corma, A., Using genetic programming for an advanced performance assessment of industrially relevant heterogeneous catalysts, Materials and Manufacturing Processes 24 (2009) 282. doi: http://dx.doi.org/10.1080/10426910802679196

30. Baumes, L. A., Collet, P., Examination of genetic programming paradigm for high-throughput experimentation and heterogeneous catalysis, Computational Materials Science 45 (2009) 27.

doi: http://dx.doi.org/10.1016/j.commatsci.2008.03.051

31. Pereira, S. R. M., Clerc, F., Farrusseng, D., van der Waal, J. C., Maschmeyer, T., Mirodatos, C., Effect of the genetic algorithm parameters on the optimisation of heterogeneous catalysts, QSAR \& Combinatorial Science 24 (2005) 45. doi: http://dx.doi.org/10.1002/qsar.200420058

32. Gobin, O. C., Martinez Joaristi, A., Schüth, F., Multi-objective optimization in combinatorial chemistry applied to the selective catalytic reduction of $\mathrm{NO}$ with $\mathrm{C}_{3} \mathrm{H}_{6}$, Journal of Catalysis 252 (2007) 205.

doi: http://dx.doi.org/10.1016/j.jcat.2007.09.025

33. Gobin, O. C., Schüth, F., On the suitability of different representations of solid catalysts for combinatorial library design by genetic algorithms, Journal of Combinatorial Chemistry 10 (2008) 835.

doi: http://dx.doi.org/10.1021/cc800046u

34. Serra, J. M., Corma, A., Farrusseng, D., Baumes, L. A., Mirodatos, C., Flego, C., Perego, C., Styrene from toluene by combinatorial catalysis, Catalysis Today 81 (2003) 425 . doi: http://dx.doi.org/10.1016/S0920-5861(03)00142-1

35. Jiang, J., Jorda, J. L., Yu, J., Baumes, L. A., Mugnaioli, E., Diaz-Cabanas, J. M., Kolb, U., Corma, A., Synthesis and structure determination of the hierarchical meso-microporous zeolite ITQ-43, Science 333 (2011) 1131. doi: http://dx.doi.org/10.1126/science.1208652

36. Rimmel, A., Teytaud, F., Cazenave, T., Optimization of the Nested Monte-Carlo Algorithm on the Traveling Salesman Problem with Time Windows, in Applications of Evolutionary Computation, Goos, G., Hartmanis, J., Leeuwen, J. V., (Eds.) 2010, Springer, p. 501.

37. Baumes, L. A., Moliner, M., Corma, A., Design of a Full-Profile-Matching Solution for High-Throughput Analysis of Multiphase Samples Through Powder X-ray Diffraction, Chemistry - A European Journal 15 (2009) 4258. doi: http://dx.doi.org/10.1002/chem.200802683

38. Baumes, L. A., Moliner, M., Nicoloyannis, N., Corma, A., A reliable methodology for high throughput identification of a mixture of crystallographic phases from powder X-ray diffraction data, CrystEngComm 10 (2008) 1321. doi: http://dx.doi.org/10.1039/b812395k 
39. Baumes, L. A., Map: An iterative experimental design methodology for the optimization of catalytic search space structure modeling, Journal of Combinatorial Chemistry $\mathbf{8}$ (2006) 304. doi: http://dx.doi.org/10.1021/cc050130+

40. Azarhoosh, M. J., Ale Ebrahim, H., Pourtarah, S. H., Simulating and Optimizing Auto-Thermal Reforming of Methane to Synthesis Gas Using Non-Dominated Sorting Genetic Algorithm II Method, Chem. Eng. Commun. (2014) doi: http://dx.doi.org/10.1080/00986445.2014.942732

41. de Smet, C. R. H., de Croon, M. H. J. M., Berger, R. J., Marin, G. B., Schouten, J. C., Design of adiabatic fixed-bed reactors for the partial oxidation of methane to synthesis gas, Application to production of methanol and hydrogen-for-fuel-cells, Chem. Eng. Sci. 56 (2001) 4849. doi: http://dx.doi.org/10.1016/S0009-2509(01)00130-0

42. Numaguchi, T., Kikuchi, K., Intrinsic kinetics and design simulation in a complex reaction network; steam-methane reforming, Chem. Eng. Sci. 43 (1988) 2295. doi: http://dx.doi.org/10.1016/0009-2509(88)87118-5

43. Trimm, D. L., Lam C. W., The combustion of methane on platinum - alumina fibre catalysts - II design and testing of a convective-diffusive type catalytic combustor, Chem. Eng. Sci. 35 (1980) 1731. doi: http://dx.doi.org/10.1016/0009-2509(80)85008-1

44. Shustorovich, E., The Bond-Order Conservation Approach to Chemisorption and Heterogeneous Catalysis: Applications and Implications, in Eley, H. P. D. D., Paul, B. W. (Eds.), Advances in Catalysis, Academic Press, 1990, 101163. doi: http://dx.doi.org/10.1016/s0360-0564(08)60364-8

45. Smith, J. M., Van Ness, H. C., Abbot, M. M., Introduction to Chemical Engineering Thermodynamics, 7th ed., McGraw Hill Higher Education, New York, 2005.

46. De Groote, A. M., Froment, G. F., Kobylinski, T., Synthesis gas production from natural gas in a fixed bed reactor with reversed flow, Can. J. Chem. Eng. 74 (1996) 735. doi: http://dx.doi.org/10.1002/cjce.5450740525

47. Elnashaie, S. S. E. H., Elshishini, S. S., Modelling, Simulation and Optimization of Industrial Fixed Bed Catalytic Reactors, in Hughes, R. (Ed.), Topics in chemical engineering, Vol. 7., Gordon and Breach Science, Amsterdam, 1993

48. Yoshida, F., Ramaswami, D., Hougen, O. A., Temperatures and partial pressures at the surfaces of catalyst particles, AICHE J. 8 (1962) 5. doi: http://dx.doi.org/10.1002/aic.690080106

49. Green, D., Perry, R., Perry's Chemical Engineers' Handbook. 8th ed, Mc Graw-Hill Companies, New York, 2006.
50. Froment, G. F., Bischoff, K. B., Wilde, J. D., Chemical Reactor Analysis and Design. 3rd ed., in Wiley Series in Chemical Engineering, John Wiley \& Sons, Hoboken, New Jersey, 2010.

51. Daubert, T. E., Danner, R. P., Sibul, H. M., Stebbins, C. C., Physical and Thermodynamic Properties of Pure Chemicals: DIPPR: Data Compilation: Supplement 10, 10th ed., Taylor \& Francis, Washington DC, 2000.

52. Treybal, R. E., Mass-Transfer Operations, McGraw-Hill Book Company, New York, 1980.

53. Gosselin, L., Tye-Gingras, M., Mathieu-Potvin, F., Review of utilization of genetic algorithms in heat transfer problems, Int. J. Heat. Mass. Tran. 52 (2009) 2169. doi: http://dx.doi.org/10.1016/j.ijheatmasstransfer.2008.11.015

54. Azarhoosh, M. J., Farivar, F., Ale Ebrahim, H., Simulation and optimization of a horizontal ammonia synthesis reactor using genetic algorithm, Rsc. Adv. 4 (2014) 13419. doi: http://dx.doi.org/10.1039/c3ra45410j

55. Shopova, E. G., Vaklieva-Bancheva, N. G., BASIC-A genetic algorithm for engineering problems solution, Comput. Chem. Eng. 30 (2006) 1293. doi: http://dx.doi.org/10.1016/j.compchemeng.2006.03.003

56. Bayat, M., Dehghani, Z., Rahimpour, M., Dynamic multi-objective optimization of industrial radial-flow fixedbed reactor of heavy paraffin dehydrogenation in LAB plant using NSGA-II method, J. Taiwan Inst. Chem. E. 45 (2014) 1474 doi: http://dx.doi.org/10.1016/j.jtice.2013.10.011

57. Etghani, M. M., Shojaeefard, M. H., Khalkhali, A., Akbari, $M$., A hybrid method of modified NSGA-II and TOPSIS to optimize performance and emissions of a diesel engine using biodiesel, Appl. Therm. Eng. 59 (2013) 309. doi: http://dx.doi.org/10.1016/j.applthermaleng.2013.05.041

58. Gosselin, L., Tye-Gingras, M., Mathieu-Potvin, F., Review of utilization of genetic algorithms in heat transfer problems, Int. J. Heat. Mass. Tran. 52 (2009) 2169. doi: http://dx.doi.org/10.1016/j.ijheatmasstransfer.2008.11.015

59. Agrawal, N., Rangaiah, G. P., Ray, A. K., Gupta, S. K., Design stage optimization of an industrial low-density polyethylene tubular reactor for multiple objectives using NSGA-II and its jumping gene adaptations, Chem. Eng. Sci. 62 (2007) 2346. doi: http://dx.doi.org/10.1016/j.ces.2007.01.030

60. Deb, K., Agrawal, S., Pratap, A., Meyarivan, T., A fast elitist non-dominated sorting genetic algorithm for multi-objective optimization: NSGA-II, Lecture notes in computer science 1917 (2000) 849 doi: http://dx.doi.org/10.1007/3-540-45356-3_83 